\title{
Gibbon E A ReLigião - Notas à \\ Margem do DeCLínIo E QUEDA \\ (ORIGENS E VITÓRIA DO CRISTIANISMO)
}

\author{
JOSÉ ANTONIO DABDAB TRABULSI \\ Universidade Federal de Minas Gerais - UFMG
}

\begin{abstract}
RESUMO
$\mathrm{T}$ ento, neste trabalho, através de uma análise passo a passo do texto de Gibbon, mostrar como a Antiguiidade clássica, anterior ao cristianismo, funcionou como arma de luta para o pensamento iluminista. Com Gibbon se estabelece o que será a relação de força predominante na época contemporânea entre a história e a religião, ou seja, afirma-se uma interpretação histórica da religião, em lugar de uma interpretação religiosa da história.
\end{abstract}

Palavras-chave: Gibbon; Historiografia; Tradição clássica; Paganismo; Cristianismo.

$\mathrm{N}$ os capítulos XV e XVI do Declínio e queda, 'de Edward Gibbon, a decadência do Império romano e a difusão do cristianismo são apresentadas como desenvolvimentos hisforça para não estabelecer uma causalidade imediata e simplista entre as duas séries de dados. Esforço inútil (se não foi puramente retórico e, precisamente, com objetivos contrários), pois esta relação veio a ser designada como o "Gibbon's problem", e isto apesar de não ter sido ele o primeiro, longe disso, a estabelecer esta relação (Momigliano, 1983, p. 331). Como freqüentemente em Gibbon, as considerações de método são utilizadas na argumentação:

\footnotetext{
${ }^{1}$ Com o objetivo de tornar as notas menos pesadas, e não cansar o leitor remetendo-o a cada instante às notas, optamos por inserir no texto as referências às passagens de Gibbon. Assim, $D Q$ (Declínio e queda) se torna a abreviação de E. GIBBON (1983), volume 1; qualquer referência ao Declinio e queda é relativa ao volume 1 , que trata da história do Ocidente, salvo indicação em contrário. É preciso também alertar o leitor para o fato de que trabalhei sobre o texto da tradução francesa, por razōes práticas mas também materiais (indisponibilidade do texto inglês em Belo Horizonte). E como a análise é muitas vezes um estudo de estilo, temo ter me colocado "em perigo" algumas vezes. Mas não tinha outra escolha.
} 
O teólogo pode se entregar ao prazer de se representar a religião como descendo do céu em todo o brilho da sua glória, e envolta em sua pureza primitiva. Uma tarefa mais triste é imposta ao historiador: ele deve descobrir a mistura inevitável de erro e de corrupção que a fé deve ter adquirido numa longa estadia entre seres fracos e degenerados. $(D Q$, p. 327)

Ele procura, assim, afastar, desde o início, a crítica cristã, através desta distinção de método.

A fim de explicar os progressos do cristianismo, Gibbon distingue cinco causas e, antes mesmo de se dar ao trabalho de enumerá-las, ele provoca uma inversão irônica entre fé e razão:

Sem dúvida esta vitória se deve à evidência convincente da própria doutrina e à providência invariável de seu grande autor: Mas não é um fato sabido que a razão e a verdade raramente encontram uma acolbida tão favorável entre os homens? (DQ, p. 327)

Após tal abordagem do assunto, ele indica as cinco causas:

1 - O zelo inflexivel e, se nos é permitido dizê-lo, intolerante dos cristãos; zelo encontrado, é verdade, na religião judaica, mas livre deste espirito estreito e insociável que, longe de convidar os gentios a abraçar a lei de Moisés, desviou-os dela. 2 - A doutrina de uma vida futura, aperfeiçoada e acompanhada de tudo que podia dar peso e força a esta verdade importante. 3-O dom dos milagres, atribuído à Igreja primitiva. 4-A moral pura e aus-tera dos fiéis. 5 - A união e a disciplina da república cristã que foi formando, por etapas, no seio do Império romano, um Estado livre, cuja força se tornava cada dia mais considerável. (DQ, p. 327-328)

No exame das características do cristianismo e do paganismo, Gibbon é acusado de favorecer este último (Baridon, 1977, p. 162), que, segundo ele, era marcado pela harmonia religiosa e pela tolerância recíproca entre as "superstições". Com uma exceção: os Judeus, que escondem assim um "ódio contra a humanidade": "mas o sábio, o humano Maimônides, ensina abertamente que se um idólatra cai n'água, um Judeu não deve impedi-lo de morrer" ( $D Q$, p. 328). Muitas observações e exemplos "assassinos" são subrepticiamente lançados por Gibbon nas notas, como este último, que não é nem um pouco excepcional, mas, ao contrário, representativo dos preconceitos anti-judaicos de Gibbon. Em relação ao judaísmo, o cristianismo parece-lhe um progresso: "um culto puro, espiritual, igualmente adaptado a todos os climas e a todos os estados do gênero humano" ( $D Q$, p. 331). 0 problema é que, em Gibbon, um elogio esconde sempre algo, como numa boneca russa, onde se deve sempre continuar procurando no interior. Aqui, após o elogio, ele introduz o seu mas, que é, no cristianismo, a obrigação de aceitar a fé e de comunicá-la aos outros.

No estilo de Gibbon, sempre é preciso buscar o sentido mais longe (Gay, 1990, p. 54); é uma das razões pelas quais sua leitura é tão instigante. Seu ceticismo, que poderia torná-lo amargo, é sempre compensado pela ironia. Assim, na análise de uma querela dos inícios do 
cristianismo, ele filosofa: "A opinião mais rigorosa impôs-se sobre a mais doce, como naturalmente era de se esperar" ( $D Q$, p. 334). Sua argumentação nunca é monótona. Quando ele ataca, adota a linha direta, quase sempre, mas muito astuciosa, alegando moderação e sugerindo que nunca irá até onde poderia. É ao mesmo tempo uma estratégia de prudência e um procedimento literário. Quando ele fala dos gnósticos, diz:

Há contra a autoridade de Moisés e dos profetas algumas objeções que se apresentam muito facilmente ao espirito cético, apesar de que estas objeções só tenham por princípio a nossa ignorância acerca de uma antiguidade muito remota, e a fraqueza do nosso espirito incapaz de formar uma idéia precisa sobre a economia divina. (DQ, p. 334)

Ou ainda, sobre as incoerências da Gênese, quando ele diz, numa nota: "O doutor Burnet discutiu os primeiros capítulos da Gênese com um tom picante demais, e com liberdade excessiva" $(D Q$, p. 335). Pode ser que Gibbon tenha considerado certas coisas, por vezes, como excessivas, mas certamente não o picante e a liberdade.

Vejamos um pouco mais em detalhe a sua análise do triunfo do cristianismo. Gibbon explica que o paganismo penetrava toda a vida privada e pública, e que era preciso muita vigilância ao cristão para escapar de sua influência. E cita Tertuliano, para o qual: "Se um amigo pagão (talvez quando alguém espirrava) se servia da expressão familiar: 'Que Júpiter 0 abençoe', o cristão era obrigado a protestar contra a divindade de Júpiter"' $(D Q$, p. 339). Dessa descrição divertida, e atestada por... Tertuliano, os cristãos saem parecendo, no mínimo, um bando de chatos.

Enquanto os cristãos agem assim, os pagãos festejam, e as festas pagãs são um enorme perigo para os cristãos. Gibbon fala $(D Q$, p. 339 , por exemplo) do paganismo de maneira neutra e "dos cristãos", como se o próprio autor se excluísse deste grupo, o que, por si só, era um insulto à religião cristã. Gibbon discorre sobre o sagrado enquanto historiador, o que era inaceitável para os fiéis, e aliás, muito raro antes dos Philosophes (Baridon, 1977, p. 832). E, quando o tom neutro não basta, ele não recua diante da provocação. Por exemplo, falando sobre a doutrina da imortalidade da alma, ele diz:

No tribunal e no senado de Roma, os oradores mais hábeis não temiam ofender seus ouvintes apresentando esta doutrina como uma opinião vã e extravagante, que todo bomem cujo espirito tinha sido cultivado pela educação rejeitava totalmente. (DQ, p. 341)

O tribunal e o senado de Roma são uma cortina de fumaça que permite a Gibbon opor um elemento fundamental da doutrina cristã à cuitura e ao bom gosto.

A doutrina da imortalidade da alma é, para o nosso autor, um terreno muito favorável. Ele desenvolve uma rápida pesquisa sobre a questão em diversos povos e religiões. Isso permite a ele privar o cristianismo de uma especificidade quanto a este ponto importante, e justamente quando o objetivo proclamado da passagem seria o de mostrar os precursores como 
uma marcha em direção à perfeição da revelação cristã. Cristãos e bárbaros tornam-se assim comparáveis, e Gibbon ainda pode caçoar. Entre os Gauleses, por exemplo: "nós podemos observar que eles confiavam, não apenas suas vidas, mas até seu dinheiro à garantia de um mundo no além" ( $D Q$, p. 342). E os cristãos não são diferentes; num tom em que ele exagera na afetação de fé e sinceridade, ele diz:

Quando a promessa de uma felicidade eterna foi oferecida aos bomens, sob a condição de adotar a crença e de observar os preceitos do Evangelho, não é surpreendente que uma proposta tão vantajosa tenha sido aceita por tantas pessoas de todas as religióes, de todos os estados, e de todas as províncias do Império romano. (DQ, p. 343)

A adesão à fé cristã se torna questão de "vantagens", quase uma pechincha de feira livre.

Simetricamente ao uso falsamente positivo dos valores cristãos, Gibbon desenvolve muitas vezes um uso falsamente negativo dos seus próprios valores, como a "razão". Assim, ele mostra que, na espera do fim do mundo, os cristãos previam as piores catástrofes e um incêndio total de Roma, sede de todos os vícios: " $O$ cristão, que fundava sua crença menos nos argumentos enganadores da razão, que na autoridade da tradição e na interpretação das escrituras, aguardava com terror e confiança esta destruição total, persuadido de que ela chegaria em breve" ( $D Q$, p. 345). Mas, em certos momentos, Gibbon pára com a brincadeira e adota um tom sério, sobretudo quando se trata de tolerância (Baridon, 1977, p. 428). Ele permeia o seu relato de condenações da intolerância. Acerca da danação prometida aos pagãos, ele desenvolve uma comparação favorável ao paganismo: "Estes sentimentos rígidos, que tinham sido desconhecidos pelo mundo antigo, pareciam ter espalhado amargura num sistema de amor e de harmonia" (DQ, p. 346). Gibbon relata também um ataque violento de Tertuliano, que ele interrompe bruscamente, dizendo: "Mas a humanidade do leitor me perdoará descer um véu sobre o restante desta descrição revoltante (...)" (DQ, p. 346). Desta forma, ele "poupa 0 leitor", e excita a imaginação do mesmo! Procedimento literário de grande efeito.

Talvez ainda mais que a imortalidade da alma, os milagres desencadeiam a ironia de Gibbon. Para comentar milagres, sua inspiração está sempre a postos:

Os dons naturais que o cristão, dizia-se, recebia ainda durante esta vida (...) Além dos prodigios que, em diferentes ocasiões, puderam ser operados pela intervenção imediata de Deus quando, para o serviço da religião, ele suspendia as leis da natureza (...). (DQ, p. 346)

Esta "suspensão das leis da natureza", para um homem do Iluminismo...

Gibbon se coloca o tempo todo fora do universo cristão (Gay, 1966, p. 207) e, às vezes, se coloca do lado pagão através da assimilação entre os seus próprios princípios e a conduta eventual dos pagãos. Assim: 
Num periodo em que a fé podia se vangloriar de ter obtido tantas vitórias surpreendentes sobre a morte, é difícil explicar o ceticismo desses filósofos que rejeitavam ou que ousavam ridicularizar a doutrina da ressurreição. Um grego de nascimento nobre, defendendo o partido do erro contra Teófilo, bispo de Antioquia, reduziu toda a disputa a um só ponto, na verdade muito importante. Ele prometeu que se pudessem mostrar a ele uma só pessoa que tivesse sido tirada do reino dos mortos, ele imediatamente abraçaria a religião cristã. É um fato muito singular que o prelado da primeira Igreja do Oriente, apesar do seu zelo pela conversão do amigo, não tenba julgado apropriado aceitar este desafio simples e razoável. (DQ, p. 347)

A razão e o cristianismo, no Declínio e queda, são como o sol e a lua: encontram-se raramente. Gibbon se coloca a lado dos que, no século XVIII, no prosseguimento do pensamento de Hume, querem submeter os milagres, e a religião em geral, à crítica histórica (Gay, 1990, p. 47). Ele não quer, ou não pode, simplesmente negar os milagres; seria talvez ainda excessivo e inaceitável na sua época e no seu meio. Procedendo então por distinções, e se perguntando em que momento cessaram os milagres, ele mostra uma diferença entre o ontem e o hoje: "Acostumados desde muito a observar e a respeitar a ordem invariável da natureza, nossa razão, ou ao menos nossa imaginação, não é suficientemente preparada para sustentar a ação visivel da Divindade" ( $D Q$, p. 349). Gibbon se salva do perigo através deste apelo ao relativismo psicológico.

Outra maneira, muito hábil, de proceder, é fazer associações que finge rejeitar, mas que são marcantes, como a que se segue: "Os cristãos foram outrora acusados de atrair para o seu partido os maiores celerados" ( $D Q$, p. 350). "Cristãos" e "celerados" estão a algumas palavras de distância e, ainda que a acusação seja rejeitada, o mal está feito, e a ligação ficará na mente do leitor. Gibbon gostava muito de Luciano (DQ, p. 351, por exemplo), e seu elogio é sintomático dos próprios procedimentos de Gibbon, onde o distanciamento crítico e a ironia ocupam lugar tão importante.

Gibbon leva a coquetterie até o ponto de se colocar em "má companhia" voluntariamente. Ele reconhece aos cristãos uma grande força de persuasão através do exemplo das virtudes:

Uma doutrina tão extraordinária e tão sublime não podia deixar de atrair a veneração do povo; mas ela não era de forma alguma apropriada para ganbar o su frágio desses filósofos mundanos que, no curso desta vida passageira, consultam apenas os movimentos da natureza e o interesse da sociedade. (DQ, p. 351)

Entre a doutrina sublime e o povo (a respeito do qual nós sabemos que Gibbon tinha a visão negativa típica de um burguês) de um lado, e os filósofos mundanos de outro, não temos nenhuma dificuldade em saber onde Gibbon estava mais à vontade. Ao lado dos judeus, o povo é outra categoria que conta pouco no pensamento de Gibbon. Falando, por exemplo, dos primeiros cristãos, ele deixa transparecer sua condição de burguês: 
É um mérito fácil tanto quanto agradâvel para as uiltimas fileiras da sociedade aquele que consiste em desprezar a pompa e os prazeres que a fortuna coloca acima de seu alcance. A virtude dos primeiros cristãos, semelbante àquela dos primeiros cidadãos da república romana, foi com frequiência preservada pela sua pobreza e pela sua ignorância. (DQ, $\mathrm{p}$. 353)

Em outros dois aspectos, o sexo e a guerra, Gibbon julga os cristãos desfavoravelmente. Ele explora as relações esquizofrênicas entre o cristianismo e o sexo com uma ironia permanente: "A enumeração das leis bizarras e minuciosas com as quais eles cercaram o leito nupcial arrancaria um sorriso ao jovem esposo, e faria enrubescer a virgem modesta" ( $D Q, \mathrm{p}$. 353). E, quando fala sobre alguns cristãos que desafiam o desejo carnal por provocação, acrescenta numa nota: "Bayle diverte seus leitores acerca deste assunto delicado" ( $D Q, \mathrm{p}$. 354). Quando comenta a aversão dos cristãos pela guerra e pelo governo, Gibbon critica: "Esta indiferença indolente ou até criminosa pelo bem público os expunha ao desprezo e à reprovação dos pagãos (...) A esta questão insultante, os apologistas do cristianismo respondiam com palavras obscuras e equívocas" ( $D Q$, p. 355). 0 sexo e a guerra são manifestações viris indispensáveis. Se, por um lado, nós sabemos muito pouco sobre a vida sentimental de Gibbon, e nada sobre a vida sexual deste celibatário convicto, por outro lado, conhecemos muito bem seu apego ao papel patriótico das armas e o seu engajamento na Milícia, que lhe roubou momentos preciosos à sua atividade de historiador. (Baridon, 1977, p. 71)

0 mais interessante é que, se os valores primordiais dos cristãos lhe parecem nefastos à vida social, quando os mesmos cristãos decidem assumir este papel, nem por isso passam a ser bem vistos por Gibbon. Ele mostra ( $D Q$, p. 355) que, apesar desta aversão, foi preciso aos cristãos se organizar e que eles então caíram, com o agravante do zelo religioso, nas disputas e paixões políticas dos pagãos. E o luxo se insinuou na comunidade cristã:

É inútil observar que os padres bumildes e piedosos que foram inicialmente revestidos da dignidade episcopal, nada possuíam e provavelmente teriam rejeitado o poder e a pompa que hoje cercam a tiara do pontífice romano ou a mitra de um prelado alemão. $(D Q, \mathrm{p}$. 357)

Na sua análise das transformações do cristianismo, podemos constatar sua hostilidade ao poder e aos métodos da Igreja:

Os prelados do século terceiro mudaram imperceptivelmente a linguagem de exortação pela do comando; eles lançaram as sementes de suas usurpações futuras, e supriram a falta de força e razão através de alegorias tiradas das santas escrituras, e através das declamações dos oradores. (DQ, p. 358)

Assim, o cristianismo se torna duplamente desqualificado: ele é desqualificado pelos seus valores de origem, e também desqualificado pelo abandono dos mesmos valores. Sobre- 
tudo, o método de Gibbon, analisando um período à luz do que aconteceu mais tarde, é uma forma de projetar sobre o passado longínquo os crimes das épocas ulteriores. Noutro sentido, os crimes do passado são utilizados por Gibbon para pôr em dificuldade os escritores eclesiásticos; é o que acontece, por exemplo, quando ele chama a atenção para a resistência que as províncias, sobretudo Orientais, opuseram à preeminência de Roma, mostrando a dureza deste combate:

A dura necessidade de condenar a memória de um papa, ou a de um santo, ou a de um mártir, embaraça boje os católicos, quando eles são obrigados a contar as particularidades de uma disputa na qual os defensores da religião se deixaram carregar pelas paixões que se revelariam mais convenientes nos acampamentos militares ou no senado. (DQ, $\mathrm{p}$. 360-361)

Quando um meio adicional de dessacralizar o assunto se apresenta, podemos ter a certeza que Gibbon não o deixará escapar.

Com uma carga tão pesada lançada contra o cristianismo, era de se esperar que o paganismo saísse de sua análise com um novo brilho, o que de fato acontece. Quando ele comenta a distinção entre leigos e clérigos, inexistente no paganismo, ele logo acrescenta, acerca dos clérigos: "Classe de homens célebres para sempre, que forneceu os atores mais importantes da história moderna, ainda que nem sempre sejam os mais edificantes" ( $D Q$, p. 361). Gibbon é um mestre incontestável da litote e, como dizia Gide, aliás, "o classicismo tende inteiramente em direção à litote". (In: Petit Robert)

Outro meio freqüentemente utilizado por Gibbon é o de provar afirmações delicadas ou ridículas para a Igreja através de testemunhos muito claros dos próprios cristãos. Assim, a respeito das doações à Igreja, ele utiliza autores cristãos e, logo em seguida, acrescenta:

(...) e que vários dos seus prosélitos tinbam vendido suas terras e suas casas para aumentar os fundos públicos da sociedade, a expensas, na verdade, de seus desgraçados filhos, que se encontravam reduzidos à mendicidade, pelo próprio fato de seus pais terem sido santos. $(D Q$, p. 362)

Vemos aqui a santidade dos pais como uma ameaça de mendicidade para os filhos. E então lembramos o medo que sempre acompanhou Gibbon quanto à integridade da sua herança, ameaçada pela impecuniosidade do seu pai (que, quanto a si, não tinha nada de um santo) (Baridon, 1977, p. 25). Mas, pelo menos enquanto as doações permaneceram voluntárias, elas foram um fato positivo e, ele acrescenta, um poderoso instrumento, pois através da caridade, elas possibilitavam a difusão do cristianismo. E ele assimila estas obras à dos missionários modernos que "salvavam" milhares de recém-nascidos em Pequim. Gibbon se situa claramente, podemos constatar de passagem, na perpectiva de uma expansão benfeitora da Europa e, por extensão, da sua religião. Ele está entre os que lamentaram sinceramente a perda 
do primeiro império colonial britânico. (Baridon in Gibbon, 1983, v. 1, p. vi)

Quando chega o momento do bałanço das causas da vitória do cristianismo, Gibbon retoma o seu tom distanciado:

A última enfim fortaleceu sua coragem pela união, dirigiu suas armas, $\boldsymbol{e}$ deu a seus esforços esta impetuosidade irresistivel, que freqüentemente tornou um pequeno grupo de voluntários intrépidos e bem disciplinados vitoriosos contra uma multidão confusa e indiferente quanto ao desenrolar de uma guerra cujo tema ela ignora. (DQ, p. 366)

Gibbon começa, pois, apregoando uma certa resignação diante do fato consumado, e um certo lamento sobre o rumo que a história não tomou. Além da força do cristianismo, a fraqueza do paganismo; ele explica que o ceticismo já tinha ganho muito espaço no interior do politeísmo, e em seguida medita: "Um estado de ceticismo e de incerteza pode distrair alguns espíritos curiosos e reflexivos; mas a prática da superstição é tão natural à multidão que, o charme rompido, ela sempre lamenta a perda de uma ilusão agradável" ( $D Q$, p. 367). Ele semeia, assim, com maestria, uma dúvida sobre a letra do que diz, pois o seu leitor sabe muito bem que a incerteza do filósofo não pode, de forma alguma, para Gibbon, ser inferior à superstição da multidão. Ele se aproveita do clima criado pelo seu discurso para imaginar, com uma afetação de medo, o surgimento de uma outra forma de superstição se, neste momento de fraqueza do paganismo, "a sabedoria da Providência não tivesse enviado à terra uma revelação pura e sã" $(D Q$, p. 368). E é então, quando tudo parece no seu devido lugar, que ele vira a expectativa e causa a surpresa: "Se nós seguirmos esta reflexão em toda a sua extensão, longe de nos surpreendermos com os progressos rápidos do cristianismo, ficaremos talvez surpresos com 0 fato de que estes sucessos não tenham sido ainda mais rápidos e mais universais" ( $D Q, \mathrm{p}$. 368). É, como dizem os franceses, "o beijo que mata", pois ele pode assim mostrar como o paganismo resistiu. Gibbon rouba a cena ao cristianismo na própria análise dos seus triunfos; pode, assim, colocar os cristãos, imediatamente, no papel de vilão. Com uma simples frase ele limpa todo o terrreno diante de si, e pode começar o seu trabalho de reconstrução do passado.

Analisando os progressos do cristianismo no Oriente, ele faz numa nota esta observação importante segundo a qual, entre as igrejas orientais, "a de Atenas parece ter sido uma das menos florescentes" ( $D Q$, p. 369). A cidade dos filósofos estava melhor armada para se defender contra a superstição; o subentendido não poderia ser mais claro. Sua análise histórica nunca é gratuita; a erudição pela erudição não faz seu gênero (Momigliano, 1983, p. 324). Frequientemente, a análise é de uma modernidade espantosa e, como podemos facilmente supor, inaceitável para a Igreja. Assim, sobre a antigüidade das igrejas do Oriente, ele diz que: "até os enxames de gnósticos e outros heréticos que de lá saíram mostram o estado florescente da Igreja ortodoxa, uma vez que a denominação de herético sempre foi aplicada ao partido menos numeroso" (DQ, p. 369). Gibbon, mestre em escrever a história "contra as fontes", 
pode perfeitamente, por causa desta sua faceta, ser considerado um precursor da "história dos vencidos"; constatamos nele o mesmo combate contemporâneo contra o establishment (mas, no seu caso, num sentido puramente intelectual, já que políticamente ele é conservador), e a mesma projeção em direção ao passado dos valores do historiador, fazendo desses valores o fio da análise histórica.

Voltemos, portanto, à análise da construção gibboniana: acerca "deste tema obscuro, mas interessante" (DQ, p. 370), ele chega a conclusões estatísticas. Utilizando fontes cristãs, ele avalia em 100.000, num total de 500.000 habitantes, o número de cristãos em Antioquia na época de Teodósio. É um dado importantíssimo para Gibbon, pois, neste caso, o que dizer da proporção de cristãos: a) antes da liberdade de culto; b) no Ocidente; c) nas aldeias; d) nas regiões recentemente convertidas? Portanto, sob a aparência de um discurso sobre os progressos do cristianismo, ele fala, na verdade, sobre a resistência do paganismo.

Após o Oriente, Roma. Analisando os progressos do cristianismo na capital do Império, ele utiliza outra vez esta retórica subliminar que é um dos segredos do seu estilo:

Nesta mistura permanente de tantos povos, um ministro da verdade ou da mentira, ofundador de uma associação criminosa ou de uma sociedade virtuosa encontrava facilmente os meios de aumentar o número de seus discípulos ou de seus cúmplices. (DQ, p. 371)

E nós, à leitura desta passagem, nos perguntamos seriamente (?) se os cristãos são "discípulos" ou "cúmplices". Mas há ainda exemplos mais interessantes e perversos; ele continua a passagem desenvolvendo um paralelo entre Tácito (falando sobre os cristãos de Roma) e TitoLívio (comentando o caso das bacanais):

Quando as bacanais acordaram a severidade do Senado, temeu-se que uma grande multidão, e por assim dizer um povo inteiro, tivesse sido iniciado nesses borriveis mistérios. Pesquisas mais exatas mostraram logo que os culpados não excediam o número de sete mil; número na verdade assustador, quando nós o consideramos como objeto da justiça pública. $(D Q$, p. 371)

E, numa nota, ele acrescenta: "Nada pôde ultrapassar o horror e a consternação do Senado, quando ele descobriu as bacanais, cuja licença desenfreada é descrita, e talvez exagerada, por Tito-Lívio" ( $D Q$, p. 371). 0 que é um cúmulo: ao mesmo tempo que não se dá o trabalho de dirimir a ambiguiidade sobre os "discípulos ou cúmplices" em relação às associações de Roma, ele ousa sugerir que a descrição das bacanais talvez tenha sido exagerada por Tito-Lívio. Fato que se torna ainda mais eloqüente quando nos lembramos que as manifestações do irracional, como as do culto báquico, não são bem vistas pelo Gibbon apólogo da razão. (Baridon, 1977 , p. 740 )

Gibbon recomeça seus cálculos, estimando em 50.000 o número de cristãos em Roma, num total de pelo menos 1.000 .000 de habitantes, ou seja, "no máximo a vigésima parte" 
$(D Q$, p. 372). Do Oriente, passando por Roma, ele chega à Gália:

Podemos julgar e nos afligir diante do estado definhante e deplorável do cristianismo nas provincias que tinbam abandonado o celta pelo latim, quando vemos que nos três primeiros séculos elas não produziram nenbum escritor eclesiástico. (DQ, p. 372)

Ora, revemos aqui a mesma insinuação já avançada em relação a Atenas. Na mente de Gibbon, Gália equivale a França que equivale a cultura. Portanto, sua ausência... Esta ausência coloca o problema da fiabilidade das fontes. 0 silêncio é tão grande que:

(...) se nós quiséssemos abordar esta época e as circunstâncias de sua fundação, para suprir o silêncio da antigüidade, seríamos forçados a recorrer a essas lendas que a avareza ou a superstição ditou, muito tempo depois, a monges preguiçosos na solidão de seus claustros. (DQ, p. 373)

Das considerações gerais, ele passa ao ataque dirigido: "Entre todas estas ficções sagradas, as aventuras romanescas do apóstolo São Tiago merecem, pela sua extravagância singular (...)" (DQ, p. 374). E ele critica então "o tribunal terrível da Inquisição", que afastou "todas as objeções de uma crítica profana" ( $D Q$, p. 374), mostrando assim sua consciência do fato de que sua "crítica profana" (própria de Gibbon) só é possivel em função da fraqueza contemporânea da Igreja.

Da longa discussão sobre os progressos do cristianismo, ele conclui que os cristãos, até a época de Constantino, na maior das estimativas, constituíam cinco por cento da população do Império. Lembremos aqui que Gibbon afirma escrever sobre "os progressos da religião e da barbárie", e que esta proporção indicada de cristãos, cinco por cento, coincide com a proporção indicada pelos historiadores, um pouco mais tarde, para o número de bárbaros no Império romano! "Mas a natureza de sua fé, de seu zelo e de sua união parecia multiplicálos" (DQ, p. 374). Portanto, após um longo desenvolvimento acerca da quantidade de cristãos, Gibbon termina seu capítulo XV com um debate sobre sua qualidade. No exame da questão sobre "se é verdade que os primeiros cristãos tenham sido ignorantes e de condição baixa", reencontramos a mesma afetação de simplicidade superior do cristianismo. A adesão dos simples é oposta aos: "felizes do século (que) se contentam da posse deste mundo, e aos sábios que, entregues a suas dúvidas, ou levados por disputas inúteis, abusam de uma vã superioridade da razão e do saber" ( $D Q$, p. 376). E, após uma listagem de sábios e escritores antigos que ignoraram o cristianismo, ele diz:

Entretanto (o que não causa menos surpresa que dor) todos estes sábios negligenciaram ou rejeitaram a perfeição da doutrina cristã. Sua linguagem ou seu silêncio mostram igualmente seu desprezo profundo pela seita nascente que, no seu tempo, tinba se espalhado pelo Império romano. (DQ, p. 376-377) 
E Gibbon, estava ao lado dos "sábios" ou da "seita nascente"? Ele sugere a resposta:

Aqueles dentre eles que se dignaram falar dos cristãos olhavam-nos apenas como entusiastas fanáticos e pervertidos, que exigiam uma submissão implícita a seus dogmas misteriosos, sem poder produzir um só argumento capaz de satisfazer um bomem sensato $e$ instruído. (DQ, p. 377)

Aqueles dentre os sábios que consideram... O leitor não precisa de um grande esforço para alinhar Gibbon entre eles.

Se no capítulo XV Gibbon analisa sobretudo os progressos do cristianismo e suas causas, no capítulo XVI ele retorna a um exame mais detido da "conduta do governo romano em relação aos cristãos, desde o reinado de Nero até o de Constantino". Seu eixo de argumentação é a dialética tolerância $v s$ perseguição. Ele começa perguntando a razão da perseguição. Tema de espanto (apenas retórico, é claro) para ele, dado o caráter "benfazejo" da doutrina cristã e a "tolerância universal do politeísmo":

(...) é difícil descobrir que nova ofensa os cristãos tinham cometido, que nova injúria tinha tornado amarga a doce indiferença da antigüidade, e tinha provocado os principes romanos, até então insensíveis ao espetáculo de todas as formas variadas da religião, que subsistiam em paz sob seu governo moderado. (DQ, p. 379)

Para Gibbon, é o cristianismo que, enquanto fato novo, afastou a "doce indiferença" do paganismo e, portanto, "provocou" o problema. Historicamente falando, a tolerância teria sido diminuída para conter a difusão do cristianismo. Ele sugere imediatamente que seu objetivo é separar, nesta questão, o "autêntico" da "ficção". E ele estabelece, logo de saída, uma relação de forças. Isto é tanto mais necessário quanto o assunto é, para Gibbon, muito delicado, tendo em vista seu apego à tolerância e o tom geral que ele quer imprimir ao seu tratamento do fato cristão:

Relatou-se com cuidado a morte de alguns mártires eminentes e, desde que o cristianismo foi revestido do poder supremo, os superiores da Igreja não se aplicaram menos a mostrar a crueldade de seus adversários idólatras que a imitar sua conduta. (DQ, p. 379)

Sua introdução do tema sugere na sua mente o esquema seguinte: provocação da violência => sofrimento e vitória $=>$ reprodução da violência.

Após esta abordagem geral do assunto, ele começa uma análise detalhada. Inicialmente, examina os motivos da perseguição: "Os direitos da tolerância apoiavam-se numa indulgência mútua; não se poderia mais reivindicá-los a partir do momento em que se recusava pagar o preço habitual" ( $D Q$, p. 379). É deste raciocínio que provém a idéia já avançada de "provocação". Judeus e cristãos estão juntos nesta posição. Gibbon é de um antisemitismo violento; ele chega a falar dos judeus como "uma raça de fanáticos", "inimigos implacáveis, 
não apenas do governo de Roma, mas de todo o gênero humano" (DQ, p. 380). A diferença é que "os judeus eram uma nação, e os cristãos uma seita" (DQ, p. 381). É interessante ver como ele provoca uma inversão, já que seu antisemitismo, que poderíamos qualificar como o vetho antisemitismo do "deicídio", é transformado, e como Gibbon chega, pelas necessidades da sua polêmica, ao ponto de se colocar do ponto de vista judeu. Falando, por exemplo, da ruptura cristã em relação ao judaísmo, ele diz: "Uma tal apostasia (se nós podemos nos servir desta expressão) (...)" (DQ, p. 382). Formulação na qual a observação entre parênteses serve para marcar sua audácia e chamar assim a atenção do leitor distraído ou ingênuo.

Este posicionamento discursivo (neutralidade aparente, na verdade arma de combate) é altamente agressivo para um leitor cristão. Mas, pelo menos, tem o mérito da clareza, na medida em que o espírito tortuoso de Gibbon nos permite falar assim. Pior ainda é a maneira como ele coloca sempre um sorriso no ar, ao restituir as críticas dos filósofos antigos ao cristianismo, manifestando uma reprovação tão explícita quanto afetada. Seu tom "inchado" denuncia a insinceridade manifesta da letra do seu discurso. Por exemplo:

Num célebre diálogo atribuido a Luciano, pretende-se ridicularizar e tratar com desprezo o dogma misterioso da trindade. Esta obra mostra como o autor conbecia pouco a fraqueza da razão bumana e a natureza impenetrável das perfeições divinas. (DQ, p. 383)

Quando nos lembramos do parentesco espiritual que existe entre Luciano e Gibbon...

Ao longo de todo o capítulo, Gibbon procura apresentar 0 assunto através de uma série de pinceladas muito hábeis. Assim, ele mostra que as reuniões de cristãos pareciam aos imperadores um desafio à sua autoridade. Mas esta atitude era, segundo ele, geral, pois a desconfiança era a regra diante de qualquer associação. Ele cita o caso (e vemos imediatamente sua intenção) de uma associação de bombeiros, em Nicomédia, proibida por Trajano. Assim, os cristãos são recolocados num contexto geral. E a grande vantagem de Gibbon é sua erudição (Momigliano, 1983, p. 326). Ele raciocina como filósofo, mas ele prova como um erudito, com citações sempre pertinentes e bem feitas; ele se torna portanto irrefutável, pelo menos quando se entra na sua lógica.

Uma outra estratégia é a de jogar os cristãos da Antiguidade contra eles próprios, e contra os cristãos modernos. Gibbon mostra a forma como seus costumes são objeto de calúnia e como eles são acusados dos mais horríveis crimes. Mas, diz ele, quando eles acusam os heréticos (que também são cristãos) dos mesmos crimes, estão fazendo, aos olhos dos pagãos, uma verdadeira confissão. Os cismáticos faziam as mesmas acusações aos ortodoxos. Isto no que se refere à Antiguidade. Os imperadores modernos (cristãos) são ainda mais culpados pelas perseguições religiosas (pois foram criados dentro do cristianismo) que os antigos. Seu discurso comparativo tende a atenuar a perseguição: 
A história, que tenta relatar os acontecimentos passados para a instrução dos séculos futuros, seria indigna deste emprego bonrado, caso se rebaixasse defendendo a causa dos tiranos ou justificando as máximas da perseguição. Entretanto, é preciso confessar, a conduta dos imperadores que apareciam como os menos favoráveis à Igreja primitiva não é certamente tão criminosa quanto a dos soberanos modernos que empregaram a arma do terror e da violência contra as opiniões religiosas de uma parte de seus súditos. $(D Q$, p. 386)

Passagem em que vemos a simetria cara ao seu classicismo, onde a chave da argumentação é dada pela fórmula de transição entre as duas metades: "entretanto, é preciso confessar...". Por outro lado, Gibbon pertence a uma época em que os conflitos religiosos começam a cansar a todos. Por isso ele se sente em posição de força para atacar a religião. E esta condenação da violência moderna, despótica (Baridon, 1977, p. 107), não deixa de se projetar positivamente sobre o politeísmo antigo e sua tolerância. (Baridon, 1977, p. 428)

Mais "compreensivel", a repressão foi, por várias razões também, muito mais lenta: "A mesma razão que torna sua conduta menos odiosa, contribuiui, segundo todas as aparências, para retardar o rigor de suas perseguições" (DQ, p. 387). E aqui intervém um elemento importante da sua análise. Ele mostra que o que é muito importante para os cristãos, e que aparece assim nas fontes cristãs, é ridiculamente pouco importante nas fontes não-cristãs da mesma época, mesmo no caso dos relatos mais cirscunstanciados. Gibbon aparece assim, mais uma vez, muito moderno no seu método. Ele mostra, em particular, como judeus e cristãos eram confundidos pelos contemporâneos. Seu antisemitismo se projeta, transborda um pouco sobre o cristianismo. Ora, Gibbon é um autor preocupado com a sorte da sua obra e espera tocar um público com idéias iconoclastas. Em outras palavras, seu ataque ao cristianismo é uma "necessidade social" do momento.

Podemos ter a medida da "fé" de Gibbon através de uma observação como a seguinte:

Talvez os judeus, mais ciumentos da sua própria fé e animados por um zelo mais violento, não tenham demorado a se aperceber que seus irmãos nazarenos se separavam cada dia mais da sinagoga; eles teriam com prazer apagado esta beresia no sangue dos que a tinham abraçado. Mas os decretos do céu tinbam já retirado qualquer arma ao seu ódio; pois alguém já lhes tinba retirado a administração da justiça criminal (...)

Eram, portanto, os romanos, mais "calmos", que julgavam. Ele estabelece aqui uma correspondência fictícia "decretos do céu" = "alguém", que esconde a correspondência real "decretos do céu" diferente de "alguém"; "alguém", na verdade, são os romanos (causas humanas) e não a Providência divina.

Isso porque as querelas entre judeus e cristãos são, para os romanos, totalmente desprezíveis: "A ignorância e o desprezo protegeram a inocência dos primeiros cristãos; e o tribunal dos magistrados idólatras tornou-se freqüentemente seu asilo mais seguro contra o fu- 
ror da sinagoga" $(D Q$, p. 388). Gibbon opera assim uma reviravolta, temporária é verdade, mas tão sutil quanto total: de perseguidores, os romanos se tornam protetores. Ainda com o apoio "indiscutível" das fontes cristãs, Gibbon minimiza $(D Q$, p. 388) o martírio e as viagens dos apóstolos. Ele relativiza tudo; acerca dos cristãos como bode expiatório do incêndio de Roma, sob o reinado de Nero, ele questiona, provisoriamente (mas mesmo assim seu argumento tem um funcionamento corrosivo), a responsabilidade de Nero no sinistro episódio. Gibbon é mais anti-católico que anti-cristão, mais anticlerical que anti-católico, e sobretudo contra a alta hierarquia:

Aqueles que contemplam com olhos curiosos as revoluções do gênero humano, podem observar que os jardins e o circo de Nero no Vaticano, que foram regados com o sangue dos primeiros cristãos, tornaram-se ainda mais famosos que o triunfo da religião perseguida, e através do abuso que ela fez de suas vitórias. No mesmo local os pontífices cristãos elevaram em seguida um templo que ultrapassa em muito os antigos monumentos da glória do Capitólio. São aqueles que, tirando de um modesto pescador da Galiléia suas pretensões à monarquia universal, sucederam ao trono de César. (DQ, p. 389)

Gibbon combate a visão da história eclesiástica sobre esta época, mostrando que o fato cristão era pouco conhecido e nada importante. Ele sublinha, por exemplo, a ignorância quase total de Plínio o Jovem, na época de Trajano, acerca dos cristãos. Fica claro que ele pretende mostrar os progressos do cristianismo como tendo sido muito lentos, e não rápidos como pretendia a história eclesiástica. Segundo ele, até a autoridade pública é indiferente à questão: "(...) e que, quaisquer que tenham sido as medidas anteriormente empregadas contra os cristãos, ainda não tinha havido decisão suficientemente respeitável nem suficientemente autêntica a ponto de servir de modelo a um magistrado romano" ( $D Q$, p. 395). Ele faz o elogio das disposições de Trajano, que não se recusa a punir, mas descarta a denúncia anônima. E, no elogio da moderação no combate anti-cristão, ele insere, como que por acaso, a lembrança do que virá a ser a atitude cristã:

Ao invés de usar o zelo implacável de um inquisidor ávido em descobrir os mais leves traços de beresia, glorificando-se com o nimero de suas vítimas, o imperador se preocupa mais em proteger o inocente que em impedir o culpado de escapar. $(D Q, \mathrm{p} .389)$

Constatamos aqui uma temática frequiente em Gibbon, que é a da autoridade pública esclarecida funcionando como uma muralha contra as paixões irracionais das multidões. No caso em questão, ele indica os clamores populares que acusavam os cristãos de responsáveis por todas as catástrofes, humanas e até naturais, mas diz que imperadores como Adriano e Antonino Pio moderaram as queixas e tomaram medidas para limitar as punições. E ele acrescenta, numa nota: "Encontramos nos autos do martírio de São Policarpo uma pintura viva destes tumultos, que eram normalmente alimentados pela malvadez dos judeus" (DQ, p. 396). Ve- 
mos aqui outra vez o preconceito cristão do deicídio. Da mesma forma como no caso dos movimentos de massa, Gibbon nos aparece nesta questão muito longe dos projetos generosos que culminarão com a emancipação dos judeus sob a Revolução.

"Relativizemos" e "citemos o adversário", são duas das divisas de Gibbon. Quando ele relata (o que ele faz) as vexações contra os cristãos, não deixa passar a ocasião de formular um julgamento sobre as fontes cristãs: "Os monges dos séculos seguintes que, em sua solidão pacífica, tiravam grande prazer em diversificar a morte e os sofrimentos dos primeiros mártires, inventaram freqüentemente tormentos de uma espécie mais refinada e mais engenhosa" ( $D Q$, p. 397). Neste sentido, ele cita fontes cristãs, entre elas Tertuliano (!) para afirmar que imperadores e magistrados foram na maior parte das vezes uma proteção: "Todas as vezes que se thes remetia um poder ilimitado, eles se serviam dele menos para oprimir a Igreja do que para socorrê-la na sua aflição" ( $D Q$, p. 398). Às vezes somos nós que sorrimos, à leitura do texto de Gibbon, como na passagem acima, ou ainda quando ele cita entre os castigos "mais brandos" infligidos aos cristãos o trabalho nas minas! E sem ironia, pelo menos perceptível.

Gibbon sempre provoca os autores eclesiásticos, citando textualmente Orígenes quando este afirma que o número de mártires foi pouco considerável:

Sua autoridade [de Orígenes] bastaria, sozinba, para destruir este exército inumerável de confessores cujas relíquias, tiradas em sua maioria das catacumbas de Roma, encheram tantas igrejas e cujas aventuras maravilhosas foram o tema de tantos romances sagrados. (DQ, p. 398)

E, numa nota: "Depois de dez séculos de um comércio livre e aberto [das relíquias], algumas suspeitas se ergueram entre os católicos instruídos (DQ, p. 398). Ou ainda: "Para dar uma idéia sobre estas lendas (...)" (DQ, p. 398). Gibbon situa, assim, romances sagrados e lendas de um lado (Baridon, 1977, p. 133), suspeitas oriundas da instrução do outro.

Gibbon sempre coloca as coisas em perspectiva; sim, houve massacres contra os cristãos, mas eles não foram os únicos. Ele mostra que quatro imperadores e suas familias também foram massacrados, no período de tempo em que São Cipriano dirigia tranqüilamente a igreja de Cartago. Outra estratégia gibboniana é situar as perseguições no contexto legal romano. Ele denuncia assim o anacronismo dos autores eclesiásticos, e afirma desta forma sua superioridade de método. Ainda acerca de São Cipriano, ele diz:

o tipo do seu suplício era o mais doce e o menos doloroso que se podia infligir a um bomem acusado de crime capital; e não se usou a tortura para forçar o bispo de Cartago a renunciar a seus princípios ou a revelar o nome de seus cúmplices. (DQ, p. 401)

Observemos, de passagem, este "cúmplices" de um santo. Após a sua morte, inclusive, funerais importantes e públicos foram realizados sem obstáculo e sem repressão. E Gibbon cita, numa nota: "M. de Tillemont ficou aborrecido ao ver afirmado de forma tão peremptória que 
não houve um só bispo entre-os mártires dos primeiros séculos" ( $D Q, \mathrm{p} .402)$. Gibbon usa todos os materiais que consegue enxergar. No martírio de um bispo ele chama a atenção... para a raridade do fato! Ele não poderia deixar de marcar este ponto contra a hierarquia da Igreja.

O tema do martírio exalta Gibbon. Entre os "diversos motivos que levavam os cristãos a buscar o martírio", ele inclui este: "A garantia de uma reputação em terra, motivo tão próprio a acariciar a vaidade do homem, animava frequientemente a coragem dos mártires $(D Q, \mathrm{p}$. 402). A "busca" do sofrimento não tinha nada para seduzir alguém como Gibbon, mas o que é mais irritante, no caso, para os cristãos, é a indicação de uma causa tão baixamente humaṇa para um fenômeno tão valorizado pelos fiéis.

Gibbon, quando faz um elogio, separa nitidamente ontem e hoje, através de um discurso sobre a diferença:

Hoje que o entusiasmo deu lugar a uma circunspecção reservada, estaríamos mais dispostos a criticar que a elogiar, mais dispostos ainda a elogiar que a imitar o fervor dos primeiros cristãos que, segundo a viva expressão de Sulpício Severo, desejavam o martírio com mais ardor que seus contemporâneos quando solicitavam um bispado.

Ele joga com o passado longínquo contra um passado mais próximo ou o presente, dizendo em suma, "cristãos, vocês não são mais o que eram"; e ele joga, ao mesmo tempo (e é fascinante observar sua maestria) o presente contra o passado, dizendo, "felizmente a razão fez progressos, e vocês já não são tão loucos quanto antes".

Esta postura de Gibbon é muito clara, pois, quanto ao martírio, ele se alinha juntamente com os filósofos antigos. Ele cita os exemplos de vários cristãos que buscam, provocam ou exigem o martírio, e diz:

Uma conduta tão digna de nota não podia escapar à atenção dos antigos filósofos; mas parece que ela lhes inspirou bem menos admiração que espanto. Incapazes de conceber os motivos que transportavam por vezes a coragem dos fiéis além dos limites da prudência ou da razão, eles atribuíam este desejo de morte ao resultado estranbo de um desespero obstinado, de uma insensibilidade estúpida ou de um frenesi supersticioso. (DQ, p. 403)

Gibbon brinca ainda, no que toca aos efeitos da passagem do tempo sobre os homens, indicando que o ardor diminuiu e que certos meios para escapar ao martírio foram reconhecidos. Esta prática, condenada por Tertuliano, excita a verve de Gibbon contra este autor: "Ele escreveu a este respeito um Tratado que é cheio do fanatismo mais extravagante e das declamações mais ridículas. É entretanto um fato curioso que Tertuliano não tenha, ele próprio, sofrido o martírio! ( $D Q$, p. 405)

Em resumo, portanto, as perseguições existiram, mas se deve desconfiar dos cristãos: "Todas as vezes que se exerceram alguns atos de severidade em diversas partes do Império, os 
primeiros cristãos deploraram e, talvez, exageraram seus próprios sofrimentos". ( $D Q, \mathrm{p} .406)$

Assim, constatamos que Gibbon ataca o cristianismo e a interpretação eclesiástica da história da Igreja, seja nos detalhes, seja no exame dos grandes problemas. Podemos citar, por exemplo, sua denúncia frequiente quanto aos absurdos cronológicos relativos aos autores e tradições cristãs. Sabemos, aliás, que os problemas de cronologia por vezes perturbaram 0 seu sono. Lembremos ainda sua retórica subliminar, quando mostra os cristãos "protegidos" pelos tiranos mais abjetos, como Cômodo, ou ainda sua maneira de lançar, como que por acaso, frases cheias de consequiências; como a seguinte, que mostra a que ponto ele enxergava cristianismo e Império como incompatíveis (Momigliano, 1983, p. 329): "A ascensão de Galiano, aumentando as calamidades do império, deu um pouco de paz à Igreja". ( $D Q$, p. 410)

É importante para Gibbon não apenas lançar dúvidas sobre a Igreja no seu conjunto, mas também sobre cristãos tomados individualmente. Mostrar que os membros da Igreja primitiva não eram seres superiores corresponde a dessacralizar a história eclesiástica. Para falar, por exemplo, dos costumes dissolutos de Paulo de Samósata, ele desarma a crítica dizendo, numa nota: "Se nós quiséssemos dissimular os vícios de Paulo, seria necessário supor que os bispos do Oriente reunidos encheram com as mais culpadas calúnias as cartas circulares que eles endereçaram a todas as igrejas do império" ( $D Q$, p. 411). Num segundo movimento, ele ataca:

Apesar destes vícios escandalosos, se Paulo de Samósata tivesse conservado a pureza da fé ortodoxa, seu reinado sobre a capital da Síria só teria terminado com o fim de sua própria vida, e se por acaso uma perseguição tivesse começado, um esforço de coragem o teria talvez elevado ao nivel dos santos e dos mártires. Mas ele tinha tido a imprudência de adotar alguns erros sutis e delicados em relação à doutrina da Trindade (...). (DQ, p. 411)

Se há um ponto em que Gibbon não tem "razão" é quando se queixa, a posteriori, do escândalo provocado pelo seu livro (o primeiro in-quarto) (Baridon, 1977, p. 152). Ele sabia muito bem onde estava indo, provocava com conhecimento de causa, e a prova disso é que se protege de todos os lados, e interpõe repetidas vezes autores cristãos como escudos:

A corrupção dos costumes e dos princípios, em relação à qual Eusébio se queixa com tanta força, pode ser considerada não apenas como uma conseqüência, mas também como uma prova da liberdade da qual desfrutavam e abusavam os cristãos sob o reinado de Diocleciano. (DQ, p. 413)

E ele prossegue, numa nota: "Os que consultarem o original (Eusébio) não me acusarão de forçar o quadro". Ou ainda: "(...) e a fé muito viva que distinguia sempre os cristãos do gentio brilhava bem menos na sua conduta do que nos seus escritos sobre temas de controvérsia".

Gibbon, quando precisa pôr numa balança fé pagã e fé cristã, por convicção ou por cálculo, se inclina em direção à segunda, pelo menos na aparência, já que nos raros casos em 
que isto acontece, ele encontra sempre motivos de recriminação:

Nunca poderíamos lamentar suficientemente que os padres da Igreja, reconbecendo que o paganismo compreendia coisas sobrenaturais, ou, como eles acreditavam, infernais, tenham aniquilado com suas próprias mãos a grande vantagem que, sem esta confissão, nós poderíamos retirar das liberais concessões dos nossos adversários. (DQ, p. 414)

Estes "momentos de fraqueza" são raros e, quer se trate de circunstâncias particulares ou de comportamentos gerais, os cristãos estão quase sempre em posição desconfortável no relato de Gibbon. Ele reduz muitas das ações que os cristãos apresentavam como sendo decorrentes da perseguição como simples resultado da lei romana, aplicada de forma habitual:

Encontrariamos poucos governos que deixariam impune a ação do centuriäo Marcelo. Um dia de festa pública, este oficial, após ter jogado seu talabarte, sua espada e as insiginias do seu estatuto, disse em alto e bom som que só obedeceria a Jesus Cristo, rei eterno, $e$ que renunciava para sempre às armas temporais e ao serviço de um senbor idólatra. (DQ, p. 415)

Quando analisa a perseguição de Diocleciano, Gibbon desaprova com firmeza a violência, que ele não pode negar. Mas, seguindo o dia a dia dos acontecimentos, indica também as possíveis razões do imperador:

No espaço de quinze dias o fogo se manifestou duas vezes no palácio de Nicomédia, até no quarto de Diocleciano; e apesar do fato de que nessas duas ocasiões ofogo tenha sido apagado antes de ter causado estragos maiores, a repetição estranba do mesmo acidente pareceu, com razão, uma prova evidente que ele não tinha sido o efeito do acaso ou da negligência. A suspeita caia naturalmente sobre os cristãos. (DQ, p. 418)

Até aqui ele se limita a uma utilização de palavras tais como "razão", "repetição estranha", "prova evidente", "naturalmente", do ponto de vista do imperador. Mas ele chega ao ponto de levantar a questão em seu próprio nome: culpados ou inocentes? "Mas como não foi possível arrancar nenhum esclarecimento sobre este complô tenebroso, parece que devemos presumir a inocência dos cristãos, ou então admirar sua firmeza" (DQ, p. 418). 0 simples fato de levantar tal questão, no contexto daquela que é considerada a pior das perseguições, soa como uma acusação aos cristãos. E, através de uma observação de método, ele parece se eximir de responsabilidade, no estilo "não me acusem, vocês têm uma imagem muito deformada dos fatos: os historiadores eclesiásticos, nossas únicas fontes acerca desta perseguição, e que nos deixaram noções incompletas e cheias de parcialidade, não sabem como explicar os temores e o perigo corrido pelos imperadores" ( $D Q, \mathrm{p} .418)$. Gibbon, enquanto historiador erudito, não podia se limitar a considerações gerais. Ele faz, portanto, um relato por região das perseguições, insistindo nos textos oficiais, condenando a violência, mas restituindo de forma neutra as acusações lançadas contra os cristãos. Em seguida, quando faz um balanço das perse- 
guições, ele começa colocando em dúvida as fontes:

Nesta exposição geral sobre a perseguição que os editos de Diocleciano inicialmente autorizavam, omiti conscientemente o quadro dos sofrimentos particulares e da morte dos mártires. Teria sido fácil para mim retirar da bistória de Eusébio, das declamações de Lactâncio e dos autos mais antigos uma longa série de pinturas horriveis e revoltantes. Poderia ter falado detalhadamente dos cavaletes e dos chicotes, dos ganchos de ferro, dos leitos em brasa, e de toda esta diversidade de tormentos que oferro e o fogo, os animais selvagens e os carrascos mais selvagens ainda podem infligir ao corpo bumano. Estas tristes cenas poderiam ter sido acompanbadas de muitas visões e milagres destinados a retardar a morte dos mártires, a celebrar seu triunfo, ou a descobrir as reliquias dos santos canonizados. Mas eu não posso determinar o que eu devo escrever, enquanto ignorar o que eu devo acreditar. Um dos mais sérios autores da história eclesiástica, Eusébio em pessoa, confessa indiretamente que relata tudo que possa aumentar a glória da Igreja, $e$ que suprime tudo que pudesse desonrá-la. (DQ, p. 426)

Nesta longa passagem ele exprime sua recusa da facilidade (e nós sabemos que Gibbon não detestava agradar o leitor pelo colorido do relato), e suas dúvidas em relação à interpretação do passado. De tudo isso, ele salva ao menos uma certeza: os historiadores eclesiásticos não são confiáveis. Gibbon mantém um olho sobre a perseguição e o outro fixado no comportamento dos cristãos. Ele chega a fazer uma lista $(D Q, \mathrm{p} .427)$ dos possiveis comportamentos errados dos cristãos, e diz: "Duas circunstâncias, entretanto, imprudentemente reveladas, fazem crer que, em geral, o tratamento dos cristãos entregues à justiça não foi tão intolerável quanto imaginamos com frequiência" ( $D Q$, p. 427). Gibbon é um ser dividido. Se, por um lado, o fidalgo Gibbon demonstra, na vida social, um cristianismo de bom tom, por outro lado, o historiador Gibbon pensa que a história da perseguição é uma história de vencedores (os cristãos), questiona o valor das fontes e tenta fazer um pouco uma história dos vencidos (os pagãos):

Quando a Igreja triunfou sobre seus inimigos, o interesse e a vaidade dos cristãos que tinham sido perseguidos os levaram a exagerar o mérito de seu respectivo sofrimento (...) as lendas mais extravagantes, desde que contribuíssem à bonra da Igreja, eram aceitas com aplauso pela multidão crédula, sustentadas pelo poder do clero, e atestadas pelo testemunbo suspeito da bistória eclesiástica. (DQ, p. 427)

Logo a seguir, sua última investida se refere ao número de mártires e a relativização deste número: "Escritores mais antigos se contentam em espalhar, desordenadamente e em profusão, invectivas patéticas, e não se preocupam em fixar o número dos que tiveram a felicidade de selar com o seu sangue a crença no Evangelho" ( $D Q, \mathrm{p}$. 427). Gibbon tem prazer em fazê-lo, e a partir de dados de Eusébio, para a Palestina, faz uma projeção numérica que dá, no total, duas mil pessoas, durante os dez anos de perseguição mais intensa. Ele chega, assim, a um total surpreendentemente baixo, e inaceitável para os cristãos. Mas o que se segue é ainda pior, um verdadeiro ataque cerrado: 
Nós terminaremos este capítulo com uma verdade triste, que, apesar da nossa repugnância, somos obrigados a reconbecer; é que, mesmo admitindo, sem besitar e sem nenbum exame, tudo o que a bistória relatou ou tudo o que a devoção inventou acerca dos mártires, devemos ainda confessar que os cristãos, no desenrolar de suas lutas internas, causaram-se a si próprios males muito maiores que os que lhes foram causados pelo zelo dos pagãos. (DQ, p. 428)

0 que abre a Gibbon a oportunidade de atacar a ortodoxia romana: "A Igreja de Roma defendeu com a violência 0 império que ela tinha adquirido pela fraude: proscrições, guerras, massacres, e a instituição do santo ofício logo desfiguraram um sistema de caridade e de paz" $(D Q$, p. 429). E ele conclui comparando os números muito mais assustadores dos massacres cristãos.

Os capítulos XV e XVI são os últimos do primeiro in-quarto, que na edição original foi publicado muito antes dos demais. Gibbon termina, como vemos, com uma acusação em regra contra o cristianismo, em que tudo que é desfavorável é explorado. A dessacralização da história da Igreja, uma revalorização do paganismo, uma revisão completa, metódica, argumentada e provada a cada passo, na maior parte da vezes através de dados dos próprios autores cristãos! Na história dos inícios do cristianismo em Gibbon, tudo era motivo de descontentamento para os leitores cristãos praticantes. Mas, mais ainda que isso, são os procedimentos narrativos, seu estilo, sua ironia, sua maneira de insinuar, de duvidar, de fingir indignação ou, ao contrário, sua maneira de se excluir da comunidade cristã que tornaram seu livro muito ofensivo. Ele não pode reivindicar inocência. Sabemos que Gibbon trabalhou sobre estes capítulos mais que sobre todos os outros, que ele os redigiu, corrigiu, condensou mais de uma vez, até que os considerasse prontos. Vemos também que ele antecipou no próprio texto respostas a muitas acusações que achava que seriam feitas contra ele.

Mas a amplitude das reações foi sem dúvida maior que a esperada, e Gibbon se sentiu no direito e no dever de responder, através de uma pequena obra, onde dá a réplica às acusações (Baridon, 1977, p. 152). E esta polêmica não deixará de marcar a redação dos volumes seguintes.

É verdade que a posição de Gibbon não era fácil, pois ele ficava dividido entre os dois pólos da sua educação (Baridon, 1977, p. 299); do lado franco-helvético, ele tirava seu desejo de liberdade, o seu lado de filósofo contestador e neo-pagão; e do lado inglês vinha o seu grande desejo de ordem e respeitabilidade. Por outro lado, ele queria ser reconhecido como um grande autor. Então, era-lhe necessário encontrar um equilíbrio: dar livre curso à contestação filosófica que estava no ar da época, mas sem ir longe demais e ultrapassar os limites do aceitável. No calor do momento, Gibbon pode ter tido medo de ter ultrapassado os limites. Mas, ainda em vida, o sucesso de sua obra e, mais ainda, a permanência da associação do seu nome a um sopro de liberdade mostram que ele teve razão em ousar tanto quanto ousou. 
TRABULSI, J. A. D.Gibbon et la religion. Notes sur Le Declin et la Chute (origines et victoire du Christianisme). Classica, São Paulo, v. 9/10, n. 9/10, p. 233-254, 1996/1997.

\title{
RÉSUMÉ
}

\begin{abstract}
T'essaie, dans ce travail, par le moyen d'une analyse serrée du texte de Gibbon, montrer la façon dont l'Antiquité classique, anterieure au christianisme, a fonctionnée comme une arme de lutte pour la pensée des Lumières. Avec Gibbon se mettent en place les rapports de force nouveaux entre histoire et religion, à savoir, l'affirmation d'une interprétation historique de la religion, à la place d'une interprétation religieuse de l'histoire.
\end{abstract}

Mots-clés: Gibbon; Historiographie; Tradition classique; Paganisme; Christianisme.

\section{Referências bibliográficas}

BARIDON, M. Edward Gibbon et le mythe de Rome. Histoire et ideologie au siècle des Lumières. Paris: Champion, 1977.

BIELMAN, A. Histoire de l'bistoire ancienne et de l'archéologie à l'Université de Lausanne, 1537 1987. Lausanne: Université de Lausanne, 1987.

BURCKHARDT, J. La civilisation en Italie au temps de la Renaissance. Paris: Plon, 2 tomos, 1885.

DEMAROLLE, J. M. La redécouverte de Julien l'Apostat à la Renaissance. In: CHEVALLIER, R. (ed.), L'influence de la Grèce et de Rome sur l'Occident moderne. Paris: Les Belles Lettres, 1977, p. 87 100.

FEBVRE, L. Le problème de l'incroyance au XVle siècle. La religion de Rabelais. Paris: Albin Michel, 1974.

GAY, P. O estilo na História. São Paulo: Cia. das Letras, 1990.

GAY, P. The enlightenment: an interpretation. The rise of modern paganism. Londres: Weidenfeld and Nicolson, 1967.

GIBBON, E. Histoire du déclin et de la chute de l'Empire Romain. Tradução Guizot. Paris: Robert Laffont, 1983.

GIBBON, E. Mémoires. Trad. de G. Villeneuve. Paris: Criterion, 1992.

GOULEMOT, J. M. Diderot mythologique (La mythologie dans les Salons), La mythologie, clef de lecture du monde classique. Tours, 1986, tomo II, p. 423-431.

GOULEMOT, J. M. Éléments pour l'analyse du texte Brutus au XVIIIe siècle. In: CHEVALLIER, R. (ed.), Influence de la Grèce et de Rome sur l'Occident moderne. Paris: Les Belles Lettres, 1977, p. 201213. 
LE GOFF, J. Histoire et mémoire. Paris: Gallimard, 1988.

LE GOFF, J. Les intellectuels au Moyen Age. Paris: Seuil, 1957.

LOSURDO, D. Rivoluzione francese e imagine dell'Antichità classica: da Constant a Nietzsche, Quaderni di storia, 26, 1987, p. 93-106.

MAHÉ, N. Le mythe de Bacchus. Paris: Fayard, 1992.

MARTIN, P.-M. Présence de l'histoire romaine dans la Révolution Française. In: CHEVALLIER, R. (ed.), Influence de la Grèce et de Rome sur l'Occident moderne. Paris: Les Belles Lettres, 1977, p. 215 226.

MICHEL, A. La mythologie chez Vico, La mythologie, clef de lecture du monde classique. Tours, 1986, tomo II, p. 411-417.

MOMIGLIANO, A. Problèmes d'bistoriographie ancienne et moderne. Paris: Gallimard, 1983.

PARKER, H. The cult of Antiquity and the French revolutionaries. Chicago, 1937.

SCHLEICH, T. Mably e le antiche costituzioni, Quaderni di storia, 23, 1986, p. 173-197.

SEZNEC, J. La survivance des dieux antiques. Essai sur le rôle de la tradition mythologique dans l'humanisme et l'art de la Renaissance. Paris: Flammarion, 1993.

VIDAL-NAQUET, P. La démocratie grecque vue d'ailleurs. Paris: Flammarion, 1990.

VOVELLE, M. Piété baroque et déchristianisation en Provence au XVIIIe siècle. Paris: Seuil, 1978. 